К. О. Мороз, А. В. Лигун, В. В. Бригадиренко

Дніпропетровський нациіональний університет ім. Олеся Гончара

\title{
СЕЗОННА ДИНАМІКА ПІДСТИЛКОВОЇ МЕЗОФАУНИ АНТРОПОГЕННО ТРАНСФОРМОВАНИХ ЕКОСИСТЕМ м. ДНІПРОДЗЕРЖИНСЬК
}

Досліджено особливості формування та сезонної динаміки фауни підстилкових безхребетних територій, що перебувають під техногенним тиском металургійної та коксохімічної промисловості. Виявлено сезонні коливання чисельності, кількості видів, зміни таксономічної та функціональної структури герпетобію. Проаналізовано динаміку рівня біорізноманіття угруповань нагрунтових артропод.

Е. О. Мороз, А. В. Лыгун, В. В. Бригадиренко

Днепропетровский наџиональный университет им. Олеся Гончара

\section{СЕЗОННАЯ ДИНАМИКА ПОДСТИЛОЧНОЙ МЕЗОФАУНЫ АНТРОПОГЕННО ТРАНСФОРМИРОВАННЫХ ЭКОСИСТЕМ Г. ДНЕПРОДЗЕРЖИНСК}

Исследованы особенности формирования и сезонной динамики фауны подстилочных беспозвоночных территорий, находящихся под техногенным прессом металлургической и коксохимической промышленности. Выявлены особенности сезонных колебаний численности, количества видов, таксономической и функциональной структуры герпетобия. Проанализирована динамика уровня биоразнообразия сообществ напочвенных артропод.

\section{K. O. Moroz, A. V. Lygun, V. V. Brygadyrenko \\ Oles’ Honchar Dnipropetrovsk National University \\ LITTER MESOFAUNA SEASONAL DYNAMICS OF ANTHROPOGENICALLY TRANSFORMED ECOSYSTEMS IN DNIPRODZERZHINSK CITY}

Peculiarities of formation and seasonal dynamics of litter invertebrates fauna in the territories under technogenic load of metallurgical and by-product coke industry are investigated. Features of the seasonal fluctuations of number, species quantity, taxonomic and functional structure of litter mesofauna are revealed. The dynamics analysis of the biodiversity of litter arthropods communities is carried out.

\section{Вступ}

В умовах техногенного тиску та антропогенної трансформації екосистем першочергове та невідкладне завдання біологічних наук - всебічне дослідження та виявлення тенденції змін структури екосистем. Установлення структури угруповань дозволить вийти на якісно новий рівень розробки прогностичних моделей функціонування екосистем задля збереження їх стійкості [4; 9]. 
Детальне дослідження тваринного населення - невід’ємного компонента екосистеми - необхідна умова для діагностики та оптимізації середовища техногенно порушених територій [5]. Як об'єкти екологічного моніторингу у першу чергу можна використовувати саме елементи мезофауни, реакція на забруднення яких проявляється у варіюванні чисельності, порушенні співвідношення трофічних груп і видового складу герпетобіонтів. Через щільний зв'язок із грунтовим горизонтом і чутливість до реакції грунтового розчину саме підстилкові безхребетні - одні з найкращих біоіндикаторів забруднення грунтів речовинами, що надходять 3 атмосфери $[1-3 ; 6 ; 7 ; 10]$.

Дніпродзержинськ - потужний промисловий центр Дніпропетровської області. Основні промислові підприємства розташовані у правобережній частині міста, вони згруповані у промислові зони. Місто налічує 58 промислових підприємств, що виділяють 108 тис. тонн шкідливих речовин на рік (15,5 \% від обласного рівня). BAT «Дніпровський металургійний комбінат ім. Дзержинського» - найбільший забруднювач повітря в місті, який викидає 89 \% шкідливих речовин. Найшкідливіші гази вуглеводні, оксиди азоту та сірки. Коксохімічний завод ВАТ «Баглейкокс» спеціалізується на переробці вугілля та сирого бензолу, а також на виробництві доменного коксу. Основні забруднювачі - коксовий пил і оксид сірки. Основні джерела викидів шкідливих газів (крім підприємств) - автотранспорт і продукти горіння, що надходять до повітряного середовища. Промислові викиди потрапляють до грунту разом з атмосферними опадами, пилом і аерозолями, а також із насиченим полютантами рослинним опадом [8].

Аналіз структурно-функціональних особливостей і сезонної динаміки популяційних характеристик угруповань підстилкової мезофауни ділянок, розташованих у зоні безпосередніх промислових викидів, дозволить виявити вплив техногенної трансформації на формування герпетобію та механізми функціонування антропогенно порушених екосистем.

\section{Матеріал і методи досліджень}

Матеріали збирали протягом вегетаційного сезону 2010 р. (квітень - жовтень) на території м. Дніпродзержинськ (Дніпропетровська обл.). Відбір підстилкових безхребетних проводили за загальноприйнятими методиками (за допомогою пасток Барбера 3 $4 \%$ розчином формаліну). За період досліджень відібрано близько 9300 екз. нагрунтових безхребетних, що належать до 145 видів.

Для дослідження сезонної динаміки герпетобію на кожній пробній ділянці у період з 19.04 по 10.10.1010 р. функціонувало по 10 пасток. Вилучення безхребетних проводили з періодичністю 7-10 діб синхронно на обох ділянках.

Пробна ділянка 1. Штучне санітарно-захисне насадження (50 м від коксохімічного заводу ВАТ «Баглейкокс»). Деревний ярус: Acer negundo L., A. platanoides L., Tilia cordata Mill., Gleditsia triacanthos L., Populus alba L., Ulmus caprinifolia Rupp. ex G. Sukcow (зімкненість деревостану - $40 \%$ ). Чагарниковий ярус відсутній. У трав'яному ярусі (проективне покриття - 65 \%) домінує Elytrigia repens (L.) Nevski (40\%), Convolvulus arvensis L., Taraxacum officinale Wigg., Capsella bursa pastoris L., Poa angustifolia L. Підстилка пухка, аморфна, потужністю 2 см. Грунт - чорнозем середньосуглинковий лісополіпшений антропогенно трансформований. Умови зволоження - мезоксерофільні.

Пробна ділянка 2. Штучне санітарно-захисне насадження (50 м від ВАТ «Дніпровський металургійний комбінат ім. Дзержинського»). Деревний ярус: Acer negundo L., Ulmus caprinifolia Rupp. ex G. Sukcow, Robinia pseudoacacia L. (зімкненість деревостану 60 \%). Чагарниковий ярус відсутній. У трав'яному ярусі (проективне по- 
криття 55 \%) домінує Elytrigia repens (35\%), також присутні Erysimum diffusum Ehrh., Reseda lutea L., Koeleria gracilis Pers., Poa angustifolia тощо. Підстилка аморфна, потужністю 5 см, дуже щільна з великою кількістю промислового сміття, азбесту, промислового пилу. Грунт - чорнозем середньосуглинковий лісополіпшений антропогенно трансформований. Умови зволоження - ксеромезофільні.

\section{Результати та їх обговорення}

Чисельність підстилкової мезофауни насадження ВАТ «Дніпровський металургійний комбінат ім. Дзержинського» більше ніж у 3,5 раза перевищує даний показник для насадження поблизу заводу ВАТ «Баглейкокс» $(4,18$ та 1,15 особин/10 пастко-діб у середньому за сезон відповідно). Але на території насадження поблизу заводу ВАТ «Баглейкокс» протягом сезону спостерігаються відносно сталі значення динамічної чисельності, тоді як на ділянці насадження ВАТ «Дніпровський металургійний комбінат ім. Дзержинського» відмічаються значні коливання чисельності: піки та спади зі значною амплітудою (рис. 1).

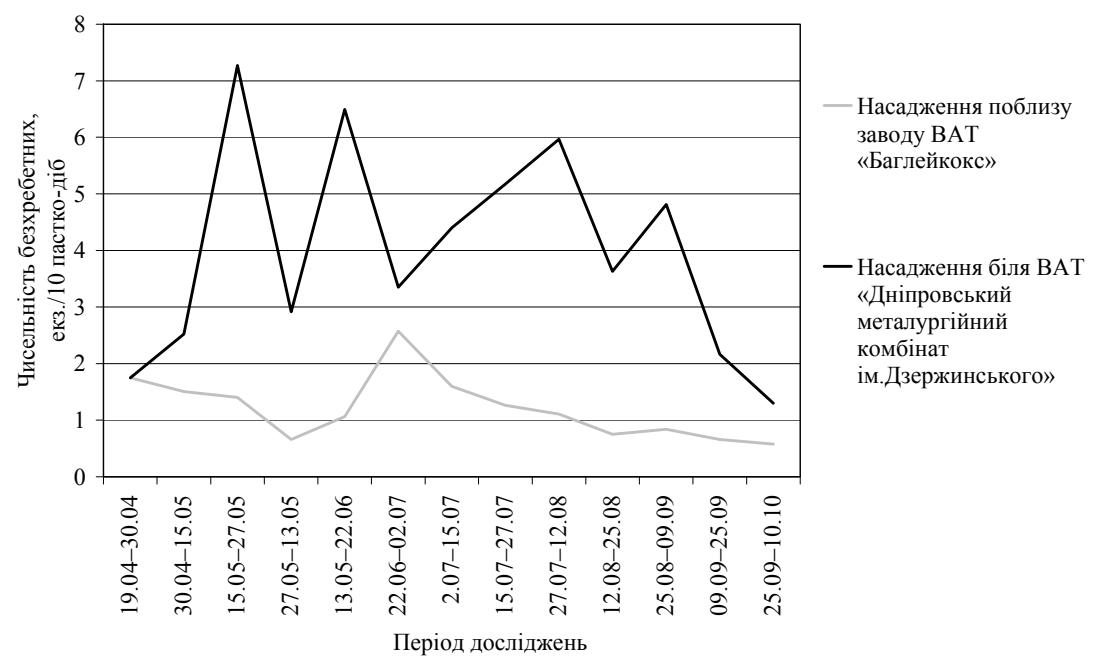

Рис. 1. Сезонна динаміка чисельності підстилкової мезофауни антропогенно трансформованих екосистем м. Дніпроджержинськ

Пік чисельності герпетобію насадження поблизу заводу ВАТ «Баглейкокс» спостерігається у другій декаді червня (2,58 особин/10 пастко-діб). Наприкінці серпня та початку жовтня даний показник досягає мінімальних значень за весь сезон спостережень $(0,58-0,66)$. На ділянці насадження ВАТ «Дніпровський металургійний комбінат ім. Дзержинського» відмічається декілька піків чисельності підстилкової мезофауни: найбільший із них (7,27 особин/10 пастко-діб) зареєстровано в середині травня. Три інші - початок червня, перші декади серпня та жовтня. Мінімальні показники (2,17 та 1,30 особин/10 пастко-діб) спостерігаються наприкінці вересня - початку жовтня та пов'язані $з$ поступовим зниженням температури повітря, скороченням тривалості світлового дня, переходом безхребетних до зимової діапаузи. Із поступовим і неодночасним виходом із неї пов'язана низька квітнева чисельність підстилкової мезофауни. Травневий пік чисельності безхребетних пояснюється переходом багатьох видів комах до статевозрілої, імагінальної стадії розвитку та масовим розмноженням герпетобіонтів. Серпнево-вересневі піки зумовлюються виходом більшості безхребетних із літньої діапаузи. Усі піки чисельності на обох пробних ділянках збігаються із 
різким зростанням чисельності окремих домінантних видів: турунів Calathus fuscipes (Goeze, 1777), мурах Formica spp. та ізопод Armadillidium sp.

За кількістю видів досліджені ділянки мало відрізняються (рис. 2). За період досліджень насадження поблизу заводу ВАТ «Баглейкокс» зареєстровано 109 видів підстилкових безхребетних, у насадженнях ВАТ «Дніпровський металургійний комбінат ім. Дзержинського» - 82. На обох територіях спостерігається подібна тенденція сезонної варіабельності видового багатства. Але на ділянці насадження поблизу заводу ВАТ «Баглейкокс» протягом сезону відмічається відносно невисока одночасна присутність різних видів у екосистемі та поступове сезонне заміщення одних видів на інші. На території насадження ВАТ «Дніпровський металургійний комбінат ім. Дзержинського» спостерігається інша картина: на фоні невисокої загальної кількості одночасно в екосистемі зустрічається більше видів, ніж на ділянці насадження поблизу заводу ВАТ «Баглейкокс».

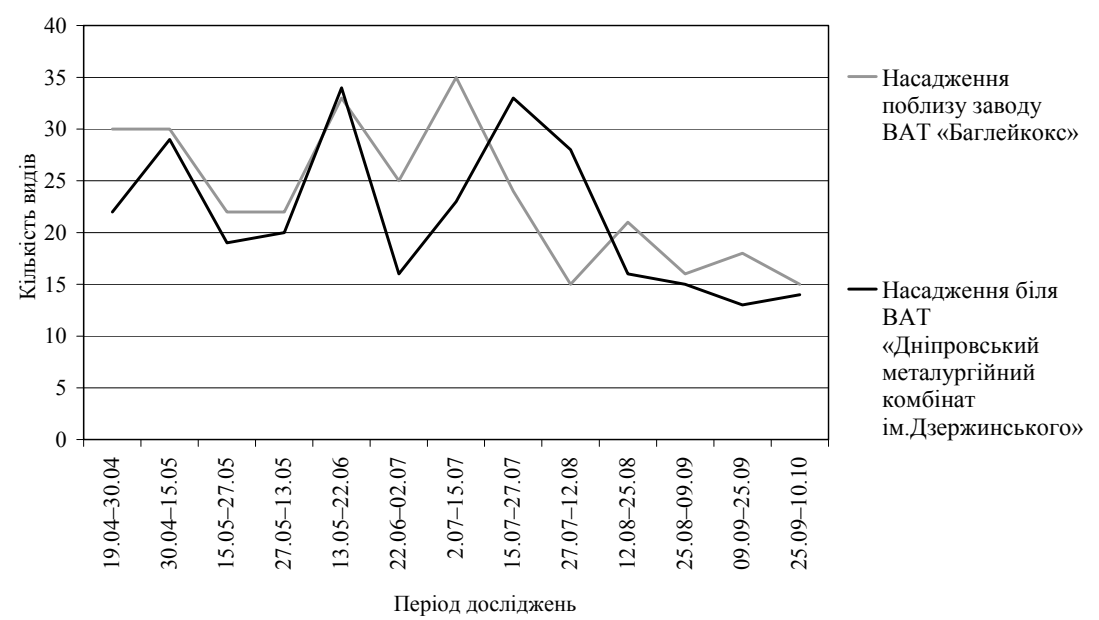

Рис. 2. Динаміка кількості видів у герпетобії антропогенно трансформованих екосистем м. Дніпроджержинськ

Два перші піки видового багатства (початок травня та перша декада червня) на обох пробних ділянках збігаються за часом і значеннями кількості видів (29-30 та 3334 види відповідно). Два інші піки припадають на липень (насадження поблизу заводу BAT «Баглейкокс» - на першу декаду, насадження ВАТ «Дніпровський металургійний комбінат ім. Дзержинського» - на другу) і досягають позначок 35 та 33 види відповідно. Найнижчі показники видового багатства у насадженнях ВАT «Дніпровський металургійний комбінат ім. Дзержинського» спостерігаються у другій декаді червня та вересня (16 та 13 видів відповідно), на насадженнях поблизу заводу BAT «Баглейкокс» - на початку липня та жовтня (15 видів). Літній спад видового багатства пов'язаний із сезонною посухою та літньою діапаузою більшості підстилкових безхребетних. Осінній - із поступовим затуханням активності артропод, закінченням вегетаційного сезону та уповільненням екосистемних процесів.

Таксономічний розподіл нагрунтових артропод суттєво відрізняється на досліджених ділянках (рис. 3, 4). У насадженнях ВАТ «Дніпровський металургійний комбінат ім. Дзержинського» основу підстилкової фауни складають представники Isopoda (42,4 \% від загальної кількості мезофауни), значна частина герпетобію представлена рядами Hymenoptera та Coleoptera (26,8 та 25,8 \% відповідно). Представники підкласу Aranei складають лише 3,2 \% герпетобію. На ділянці насадження поблизу заводу ВАТ 96 
«Баглейкокс» головну роль у формуванні мезофауни відіграють представники ряду Coleoptera (42,8 \%). Значна частина герпетобію представлена безхребетними підкласу Aranei та ряду Isopoda (17,6 та 15,8 \% відповідно). На відміну від насадження ВАТ «Дніпровський металургійний комбінат ім. Дзержинського», 9,1 \% мезофауни насадження поблизу заводу ВАТ «Баглейкокс» припадає на представників ряду Dermaptera. Hymenoptera складають лише 8,0 \% підстилкової мезофауни ділянки насадження заводу ВАТ «Баглейкокс».

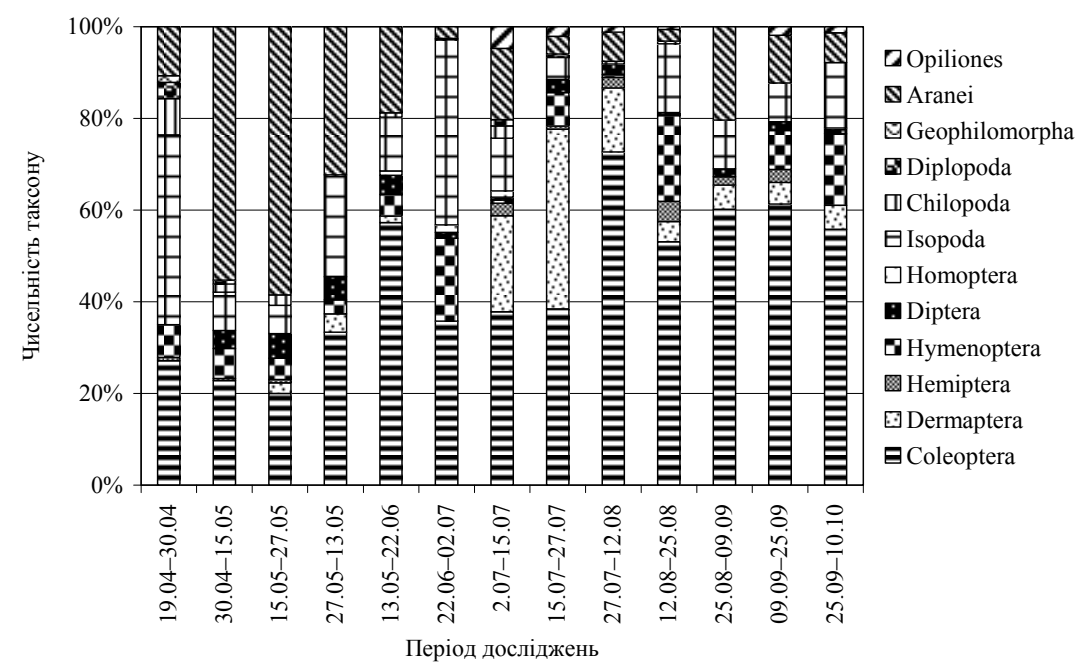

Рис. 3. Сезонна динаміка таксономічної структури герпетобію ділянки насадження поблизу заводу ВАТ «Баглейкокс» (м. Дніпродзержинськ)

Представники підкласу Aranei домінують у мезофауні насадження поблизу заводу ВАТ «Баглейкокс» наприкінці весни (див. рис. 3) та досягають максимальної чисельності у першій декаді травня (58,5 \% від загальної чисельності герпетобію). Влітку чисельність павуків різко знижується: мінімальна вона на початку червня та у другій декаді серпня (2,6 та 2,5 \% відповідно). Відносна чисельність колеоптерофауни насадження поблизу заводу ВАТ «Баглейкокс» поступово підвищується протягом вегетаційного сезону та досягає максимуму у другій декаді липня (72,7 \%). Протягом серпня жовтня представники ряду Coleoptera складають 50,0 \% від кількості герпетобію. Динаміка відносної чисельності представників ряду Isopoda коливається протягом сезону зі значною амплітудою. У другій декаді квітня та червня ізоподи домінують у нагрунтовій мезофауні ділянки насадження поблизу заводу ВАТ «Баглейкокс» $(41,4$ та 40,3 \% відповідно). Наприкінці липня - на початку серпня представники даного таксона в герпетобії не зареєстровані. Суттєві перепади чисельності таксона пояснюються залежністю суходольних ракоподібних від мікрокліматичних умов навколишнього середовища. Особливості біології зумовлюють значне зниження чисельності даного таксона у період літньої посухи (липень - серпень). Протягом липня на фоні суттєвого зниження через літню діапаузу відносної кількості більшості таксонів підстилкових безхребетних значної чисельності досягають представники ряду Dermaptera. У другій декаді липня вони складають 39,1 \% мезофауни ділянки насадження поблизу заводу ВАТ «Баглейкокс».

На ділянці насадження ВАТ «Дніпровський металургійний комбінат ім. Дзержинського» 3 початку квітня до першої декади липня у мезофауні домінують представники ряду Isopoda (див. рис. 4). Максимум їх чисельності зареєстровано у другій 
декаді травня (80,8 та 79,1%). Починаючи 3 другої декади липня чисельність Isopoda різко знижується і до кінця сезону спостережень не перевищує 28 \%. Максимальна відносна чисельність представників ряду Coleoptera спостерігається у період із кінця липня до першої декади вересня (до 49,7 \%). Найнижчий показник зареєстровано у середині травня (2,7 \%). Наприкінці квітня - на початку травня близько 23 \% герпетобію складають представники ряду Нуmenoptera. Із другої декади травня до початку липня відносна чисельність Нуmenoptera суттєво знижується та не перевищує 8,0\%. Починаючи 3 другої декади липня Нуmenoptera поступово підвищують активність до 65,1 \% у першій декаді жовтня. Максимальні показники відносної чисельності представників підкласу Aranei зареєстровано у середині травня (8,4 \%). Починаючи 3 першої декади липня чисельність павуків суттєво знижується, мінімальні значення $(0,43 \%)$ спостерігаються наприкінці серпня.

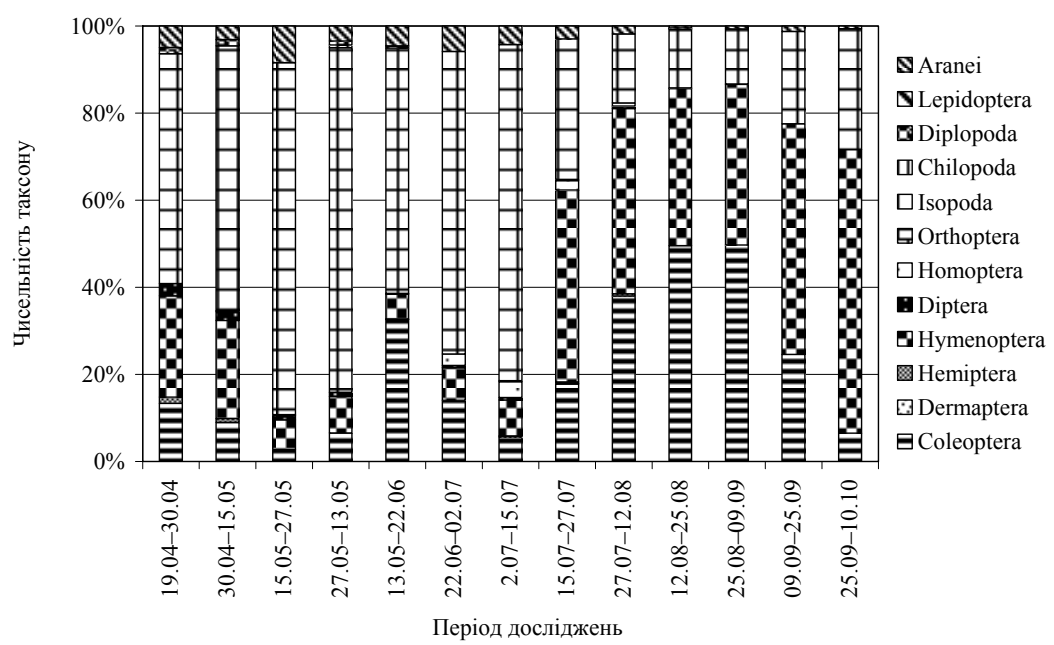

Рис. 4. Сезонна динаміка таксономічної структури герпетобію ділянки насадження поблизу ВАТ «Дніпровський металургійний комбінат ім. Дзержинського» (м. Дніпродзержинськ)

Розподіл трофічної структури мезофауни (рис. 5,6 ) антропогенно трансформованих екосистем м. Дніпродзержинськ має суттєві відмінності. На ділянці насадження ВАТ «Дніпровський металургійний комбінат ім. Дзержинського» 49,8 \% підстилкових безхребетних складають зоофаги за рахунок великої чисельності твердокрилих родини Carabidae. Фітосапротрофний блок становить $16,3 \%$. Через домінування у таксономічному розподілі Isopoda 42,6 \% трофічної структури насаджень поблизу заводу ВАТ «Баглейкокс» складають фітосапрофаги, зоофаги становлять лише 27,3%. Проективне покриття трав'яного ярусу досліджених ділянок безпосередньо впливає на розподіл трофічної структури мезофауни: фітофаги насадження поблизу заводу ВАТ «Баглейкокс» складають близько 14, а на території насадження ВАТ «Дніпровський металургійний комбінат ім. Дзержинського» - лише 2,9\%. Частка безхребетних-пантофагів на обох досліджених ділянках суттєво не відрізняється (18,5 \% у насадженнях поблизу заводу ВАТ «Баглейкокс» та 26,8 \% у насадженнях ВАТ «Дніпровський металургійний комбінат ім. Дзержинського»). Два відсотки трофічної структури насаджень поблизу заводу ВАТ «Баглейкокс» становлять копрофаги, а у насадженнях ВАТ «Дніпровський металургійний комбінат ім. Дзержинського» - лише 0,4 \%. Некрофільна ланка герпетобію насаджень ВАТ «Дніпровський металургійний комбінат ім. Дзержинсько- 
го» складає лише $0,01 \%$. На території насаджень заводу ВАТ «Баглейкокс» жодного представника некрофагів за період досліджень не зареєстровано.

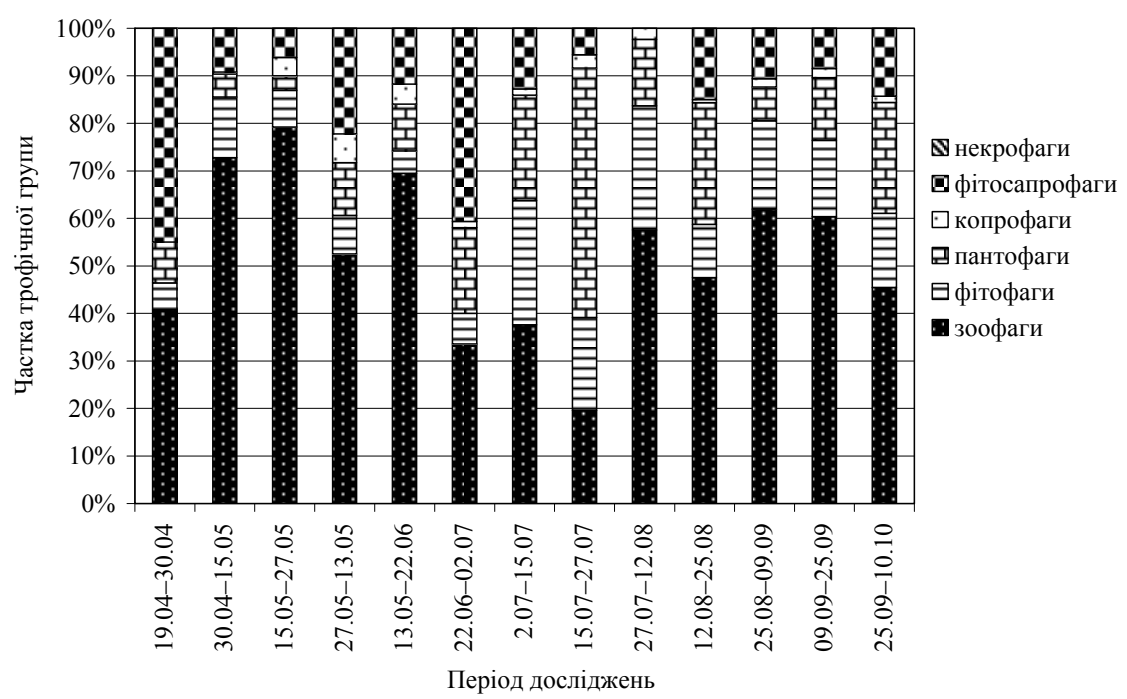

Рис. 5. Сезонна динаміка трофічної структури підстилкової мезофауни насадження поблизу заводу ВАТ «Баглейкокс» (м. Дніпродзержинськ)

Пік чисельності блоку зоофагів на ділянці насадження поблизу заводу ВАТ «Баглейкокс» зареєстровано у першій декаді травня (див. рис. 5). Далі спостерігається поступове зниження активності представників даного трофічного рівня, і у першій декаді липня чисельність зоофагів сягає мінімальних значень, дорівнюючи чисельності фітофагів (20 \%). Максимальна кількість фітофагів (26 \%) спостерігається наприкінці червня. У першій декаді липня трофічну структуру насаджень поблизу заводу ВАТ «Баглейкокс» формують пантофаги (52 \%), що зумовлено підвищенням активності Dermaptera. Поступово чисельність пантофагів знижується, і наприкінці вересня - на початку жовтня складає 21,3 \%. Пригнічення активності пантофагів (11 \%) у середині травня зумовлює підвищення частки копротрофного блоку дослідженої екосистеми. Пік активності фітосапрофагів припадає на середину червня (41 \%). Поступово активність фітосапрофагів знижується. У зв'язку з літньою діапаузою у середині липня вони повністю випадають із трофічної мережі герпетобію. Починаючи з кінця липня початку серпня частка фітосапрофагів підвищується та наприкінці вегетаційного сезону складає $14 \%$ чисельності мезофауни.

На території насаджень ВАТ «Дніпровський металургійний комбінат ім. Дзержинського» зареєстровано два піки активності зоофагів: перший припадає на кінець травня - першу декаду червня, другий $(50$ \%) - наприкінці липня - на початку серпня (див. рис. 6). Далі спостерігається пригнічення активності даного трофічного блоку, i наприкінці вегетаційного сезону зоофаги складають лише 5,3 \% від загальної кількості герпетобію дослідженої ділянки. Пік активності фітотрофів $(5,4$ \%) припадає на кінець травня - першу декаду червня, мінімальних значень даний показник сягає наприкінці липня - на початку серпня і до кінця сезону не перевищує $2 \%$. Мінімальна кількість пантофагів зареєстрована наприкінці травня - у першій декаді червня, але протягом сезону поступово підвищується та на початку жовтня формує ядро трофічної структури герпетобію (65 \%). Максимальну чисельність копрофагів зареєстровано у першій декаді травня. В інші періоди відсоток даного трофічного блоку лишався незначним. 
Максимальних значень частка фітосапрофагів сягає у першій декаді травня, наприкінці серпня - на початку вересня, навпаки, спостерігається значне зниження чисельності (13\%). Наприкінці вегетаційного сезону фітосапрофаги складають 28 \%. Некрофаги за період досліджень зареєстровані лише на початку липня.

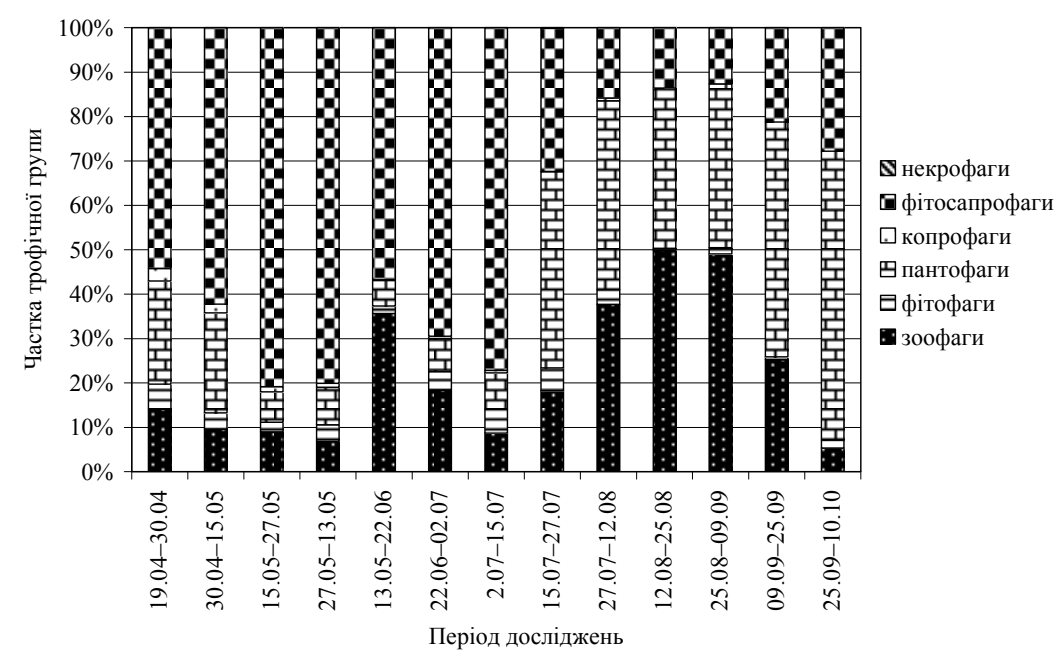

Рис. 6. Сезонна динаміка трофічної структури герпетобію насадження

ВАТ «Дніпровський металургійний комбінат ім. Дзержинського» (м. Дніпродзержинськ)

Рівень біорізноманіття суттєво не відрізняється на обох досліджених ділянках і $€$ досить низьким (рис. 7). Індекс Шеннона для насадження ВАТ «Дніпровський металургійний комбінат ім. Дзержинського» у середньому складає 2,08, а індекс Пієлоу - 0,754 біт. Для мезофауни насадження поблизу заводу ВАТ «Баглейкокс» ці показники дещо вищі: 3,38 та 0,754 біт відповідно.

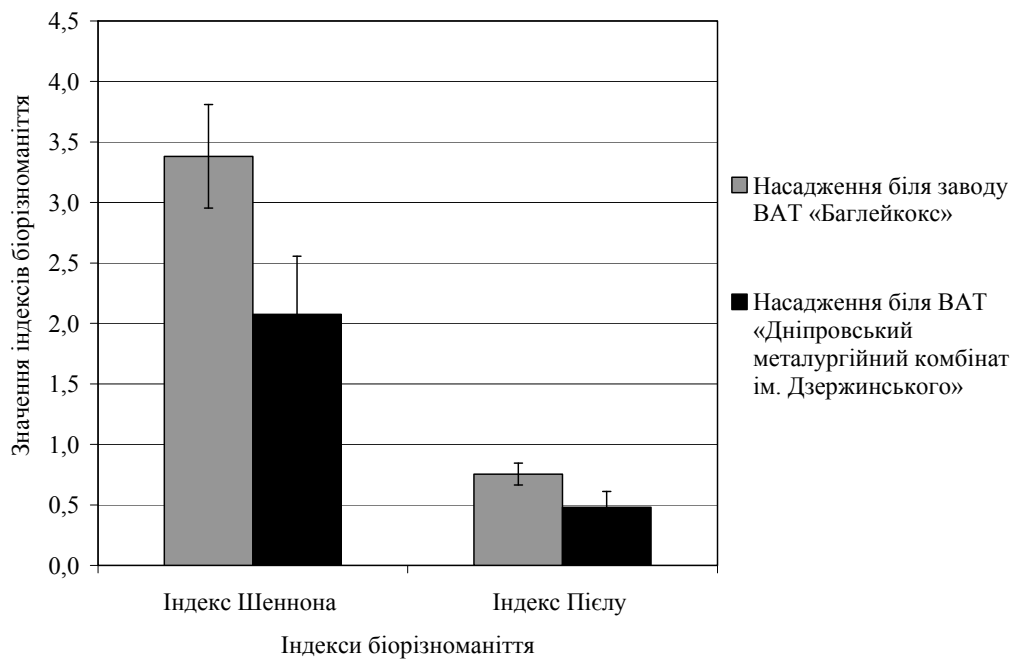

Рис. 7. Біорізноманіття угруповань підстилкової мезофауни антропогенно трансформованих екосистем м. Дніпроджержинськ

Найнижчі індекси різноманіття мезофауни для насадження ВАТ «Дніпровський металургійний комбінат ім. Дзержинського» (рис. 8) зареєстровано у другій декаді трав- 
ня (1,23 та 0,29 біт відповідно). Максимальні показники індексу Шеннона $(2,91)$ спостерігаються наприкінці липня та протягом подальших досліджень складають близько 2,3 біт. Найвищі значення еквітабільності угруповань підстилкових артропод зареєстровано в середені вересня $(0,64)$, надалі цей показник коливається в межах 0,58 біт.

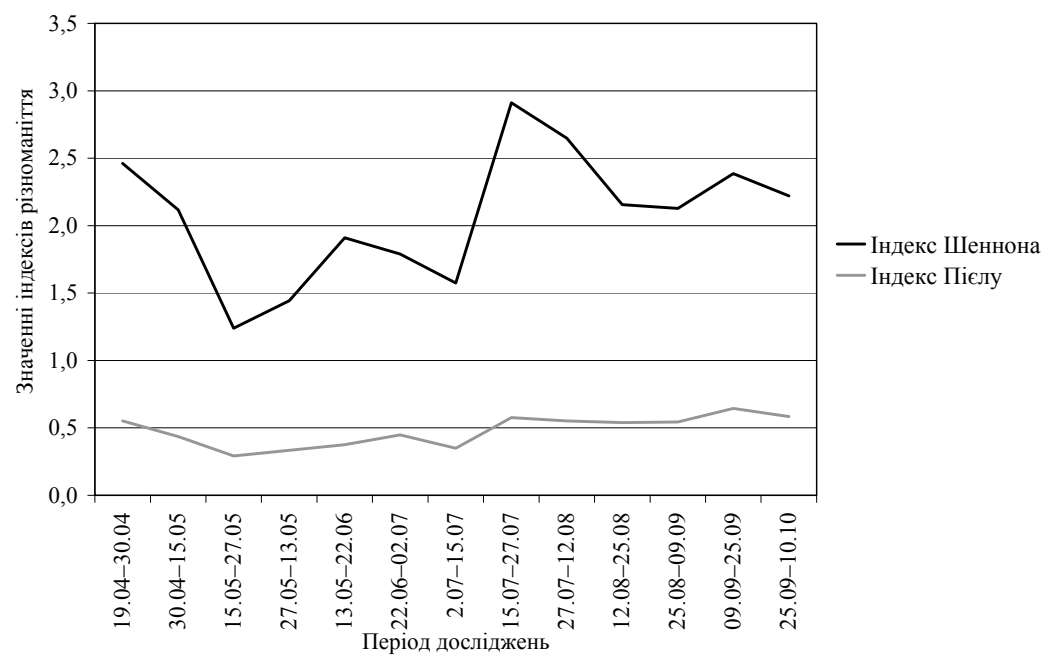

Рис. 8. Сезонна динаміка біорізноманіття герпетобію насадження поблизу

ВАТ «Дніпровський металургійний комбінат ім. Дзержинського» (м. Дніпродзержинськ)

На території насадження поблизу заводу ВАТ «Баглейкокс» максимальні значення індексу Шеннона (рис. 9) спостерігаються на початку липня (4,18 біт). У другій декаді липня - на початку серпня зареєстроване зниження ентропії герпетобію $(2,90)$, та 3 другої декади серпня до кінця вегетаційного сезону показник поступово підвищується (близько 3,40 біт).

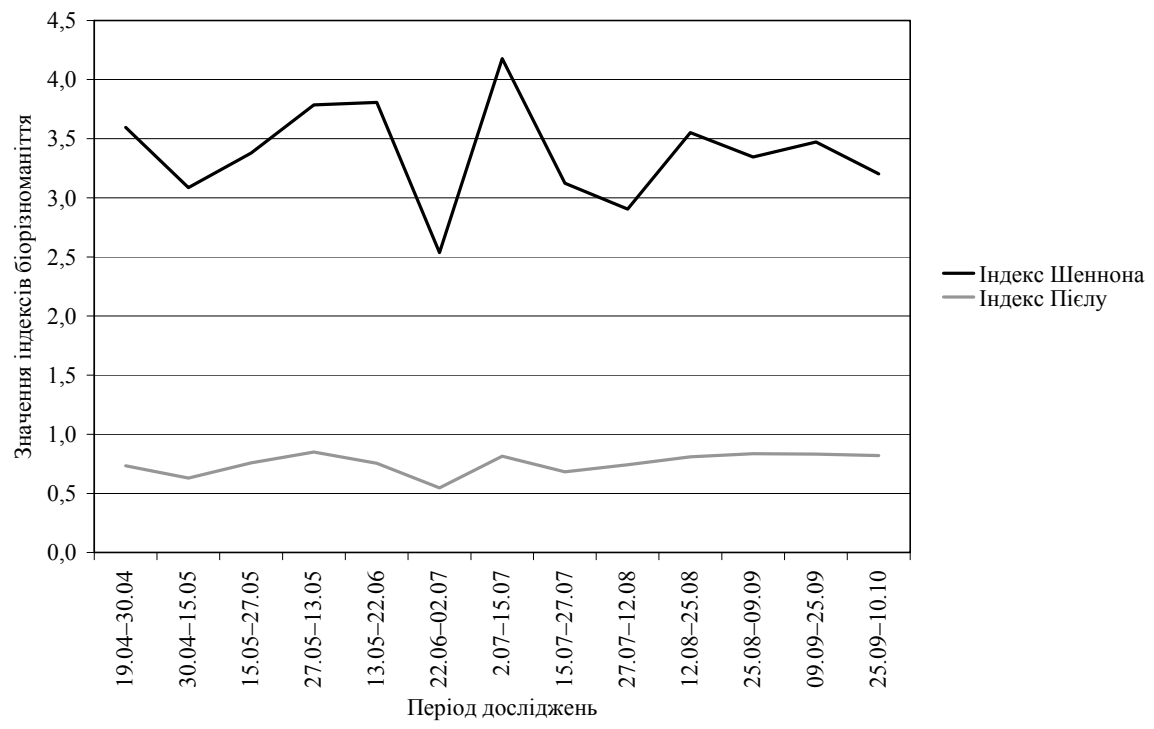

Рис. 9. Сезонна динаміка біорізноманіття угруповань підстилкових артропод насадження поблизу заводу ВАТ «Баглейкокс» (м. Дніпродзержинськ) 
Максимальні значення індексу Пієлу $(0,85)$ спостерігаються на початку липня, мінімальні $(0,55)$ - у першій декаді серпня. Починаючи з середини серпня еквітабільність мезофауни підвищується, до кінця жовтня тримається на рівні близько 0,8 біт.

\section{Висновки}

Характеристики угруповань підстилкових безхребетних антропогенно трансформованих ділянок м. Дніпродзержинськ мають досить низький рівень. Чисельність герпетобію насадження ВАТ «Дніпровський металургійний комбінат ім. Дзержинського» більше ніж у 3,5 раза перевищує даний показник герпетобію насадження поблизу заводу ВАТ «Баглейкокс», але на останній ділянці зареєстровано на 30 видів більше. Основу трофічної структури підстилкової мезофауни насадження ВАТ «Дніпровський металургійний комбінат ім. Дзержинського» складають зоофаги, тоді як у насадженні поблизу заводу ВАТ «Баглейкокс» основу герпетобію становлять фітосапрофаги. Таксономічна структура та рівень біорізноманіття угруповань підстилкових безхребетних обох досліджених ділянок суттєво не відрізняється.

\section{Бібліографічні посилання}

1. Бессолицына Е. П. Изменение структуры зооценозов почв подтаежного ландшафта в условиях техногенного воздействия // География и природные ресурсы. - 1990. - № 4. - С. 104-108.

2. Гиляров М. С. Роль почвенных животных в разложении растительных остатков и круговороте веществ / М. С. Гиляров, Б. Р. Стриганова // Итоги науки и техники. Зоол. беспозвоночныХ. М. : ВИНИТИ, 1978. - Т. 5. - С. 8-69.

3. Гиляров М. С. Почвенные беспозвоночные как индикаторы почвенного режима и его изменений под влиянием антропогенных факторов // Биоиндикация состояния окружающей среды Москвы и Подмосковья. - М., 1982. - С. 8-11.

4. Емельянов И. Г. Разнообразие и его роль в функциональной устойчивости и эволюции экосистем. - К., 1999. - 168 с.

5. Клауснитцер Б. Экология городской фауны. - М. : Мир, 1990. - 246 с.

6. Криволуцкий Д. А. Почвенные животные как биоиндикатор при экологическом нормировании нарушений природной среды // Проблемы почвенной зоологии. - Минск, 1978. - С. 123-124.

7. Методы почвенно-зоологических исследований / Под ред. М. С. Гилярова. - М. : Наука, 1975. $-280 \mathrm{c}$.

8. Пасічний Г. В. Геоекологічні моніторингові дослідження вмісту важких металів у грунтах техногенно змінених ландшафтів (на прикладі м. Дніпродзержинська) / Г. В. Пасічний, С. М. Сердюк // Вісник Дніпропетр. ун-ту. Геологія. Географія. - 2002. - Вип. 4. - С. 161-166.

9. Северцов А. С. Внутривидовое разнообразие как причина эволюционной стабильности // Журн. общ. биол. - 1990. - Т. 51, № 5. - С. 579-589.

10. Стриганова Б. Р. Трофические отношения почвенных животных и их зональноландшафтные особенности / Б. Р. Стриганова, Ю. И. Чернов // Структурно-функциональная организация биогеоценозов. - М. : Наука, 1980. - С. 269-288.

Надійшла до редколегіï 25.05.2011 